\title{
REVOLUÇÃO FARROUPILHA EM CENA: REPRESENTAÇÃO, VIOLÊNCIA E MEMÓRIA NO JORNAL O POVO E NO FILME O TEMPO E O VENTO
}

\author{
LAÍSA VERONEZE BISOL \\ URI câmpus Frederico Westphalen \\ Frederico Westphalen, Rio Grande do Sul, Brasil \\ E-mail:bisol@uri.edu.br. \\ LUANA TEIXEIRA PORTO \\ URI câmpus Frederico Westphalen \\ Frederico Westphalen, Rio Grande do Sul, Brasil \\ E-mail: luana@uri.edu.br.
}


REVOLUÇÃO FARROUPILHA EM CENA: REPRESENTAÇÃO, VIOLÊNCIA E MEMÓRIA NO JORNAL O POVO E NO FILME O TEMPO E O VENTO

Resumo: Este artigo aborda o modo como as temáticas da violência e da guerra são representadas em discursos de ordem ficcional e não-ficcional, com o intuito de verificar qual a memória histórico-social constituída. Os objetos analisados são o jornal $O$ Povo e o filme $O$ tempo e o vento. O periódico emite uma opinião exclusiva sobre os temas, enquanto filme superestima outros elementos em detrimento da problemática da violência.

Palavras-chave: Guerra, Violência, Memória, O Povo, O tempo e o vento.

FARROUPILHA REVOLUTION ON THE SCENE: REPRESENTATION, VIOLENCE AND MEMORY IN THE NEWSPAPER O POVO AND IN THE MOVIE O TEMPO E O VENTO

Abstract: This paper addresses how the themes of violence and war are represented in discourses of fictional and non-fictional order in order to verify which is the historical-social memory formed. The objects of study are the newspaper $O$ Povo and also the movie $O$ tempo e o vento. The periodical emit a unique view on the topics, and the movie overestimates other elements to the detriment of the problematic of violence.

Keywords: War, Violence, Memory ,O Povo, O tempo e o vento.

REVOLUCIÓN FARROUPILHA EN ESCENA: LA REPRESENTACIÓN , LA VIOLENCIA Y LA MEMORIA EN EL PERIÓDICO O POVO Y LA PELÍCULA O TEMPO E O VENTO

Resumen: Este artículo aborda el modo como las temáticas de la violencia y de la guerra son representadas en discursos de orden ficcional y no-ficcional, con el objetivo de verificar cual es la memoria histórico-social constituida. Los objetos analizados son el periódico El Pueblo y la película El tiempo y el viento. Constatamos que el periódico emite una opinión exclusiva sobre los temas, mientras película enfatiza otros elementos en detrimento de la problemática de la violencia.

Palabras clave: Guerra; Violencia; Memoria; El Pueblo; El tiempo y el viento. 


\section{CONSIDERAÇÕES INICIAIS}

A Revolução Farroupilha é um evento histórico do Rio Grande do Sul que foi objeto de referenciação em jornais da época, que acentuavam na caracterização dos fatos perspectivas ideológicas do século XIX, e em produções artísticas posteriores, que procuram "recuperar" esse episódio de modo a dialogar com um determinado perfil de público. Essa Revolução ocorreu entre 1835 e 1845 e originou-se de uma insatisfação do povo gaúcho diante das autoridades imperiais, época em que, segundo a historiadora Sandra Pesavento (2003, p. 44), em outras regiões país, também com economia subsidiária, acumulavam-se ressentimentos. Dentre os traços Revolução Farroupilha está a violência, contudo, nem todos os discursos sobre esse evento têm explorado essa faceta de modo crítico ou questionado o uso da força e da guerra para a transformação social e conquista coletiva.

A violência e a guerra são tópicos que fazem parte do imaginário e da cultura brasileira e podem ser apontados como constantes na história social do Brasil. Talvez por isso e, certamente pela sua intensidade, os temas são abordados em discursos de ordem não-ficcional, enquanto registro e veiculação de informações, mas também no campo das artes, como na pintura, na fotografia, no cinema e na literatura.

Em relação à abordagem das artes em torno da temática da violência, de modo específico, ora de forma mais crítica, ora de forma mais referencial, cabe fazer alusão à pesquisa de Jaime Ginzburg (2013), que aponta a grande importância do debate sobre este tema. Segundo o autor, a violência não é justificável em nenhuma hipótese e, através da análise do discurso literário, torna-se possível, por exemplo, refletir sobre o que motiva as personagens a agirem de forma violenta. Cabe refletirmos, desta maneira, quais outros discursos ajudam a compreender estas motivações e de que maneira interferem na construção da reflexão social.

Nesse sentido, nossa proposta é discutir se, na produção cinematográfica O tempo e o vento, de Jayme Monjardim baseada na obra literária de mesmo título, e no jornal O Povo, que circulou no século XIX, período da Revolução Farroupilha, podemos encontrar a possibilidade de reflexão acerca das motivações e consequências violência originária da guerra. A partir da leitura desses discursos, procuramos desvendar qual é a memória suscitada por elas, considerando o seu contexto de produção. Para tanto, nosso objetivo é responder ao seguinte questionamento: como se constrói a represen- 
tação da violência oriunda da guerra nestes discursos e que perspectiva de memória sócio-histórica é construída a partir destes textos?

\section{CONSTRUÇÃO DA MEMÓRIA}

Para representar os fatos e situações, quem escreve precisa recorrer à memória, seja ela advinda de suas próprias experiências ou unida a fatores externos que possibilitam a imitação da realidade através dos discursos. A partir disso, quem recebe, decodifica e reflete acerca das narrativas tem mais um elemento constitutivo de sua própria memória, que se une à do autor para criar novos significados.

Isto quer dizer que, embora um fato histórico seja representado, a fim de materializar a memória de determinados acontecimentos, diferentes perspectivas podem tomar forma, uma vez que o passado une-se com as experiências atuais. Diante disso, Walter Benjamin (1994, p. 224) afirma que "articular historicamente o passado não significa conhecê-lo 'tal como ele de fato foi'. Significa apropriar-se de uma reminiscência, tal como ela relampeja no momento de perigo". Desta maneira, compreendemos que a memória representada nas narrativas registra os fatos, mas é acrescida de informações atualizadas de acordo com o tempo de agora.

A memória construída a partir daquilo que se tem como registro, portanto, não é unicamente individual. Ela perpassa, em maior medida, pela lembrança e construção de muitos envolvidos, desde a participação nos acontecimentos à transformação em narrativa e, sobretudo, naquilo que se constrói em sociedade para a formulação de identidades. A constituição da memória se dá, conforme Maurice Halbwachs (2006), a partir das nossas lembranças unidas à percepção do presente. $O$ autor destaca que há duas formas de organização das lembranças, uma delas, centrada no próprio indivíduo com suas percepções, que seria a memória individual, e outra, inserida em uma sociedade, com ideias compartilhadas, configurando-se na memória coletiva.

À medida que consideramos que a memória pode ser exterior, entendemos também que nem todas as recordações advêm de vivências particulares, podendo, conforme as ideias do autor, ser transmitidas através de outrem, por meio de testemunhos ou de acontecimentos evidenciados através de jornais, livros ou outros elementos que contribuem para a memória de muitas pessoas, ainda que não tenham vivenciado as situações, mas souberam a partir destes dados. 
Dessa maneira, ainda que indivíduos não tenham participado ativamente de momentos marcantes ou até mesmo históricos, é possível que esta memória seja resgatada e imbuída entre as suas experiências, uma vez que são diversas as formas de se ter acesso às informações que podem, inclusive, tornarem-se importantes para grupos ou a uma nação, a ponto de tornarem-se tradição e incluírem estes mesmos indivíduos em determinados costumes através da identificação com aqueles fatos.

Se através dos diferentes discursos as temáticas permeiam, então, a memória de grupos, estes acontecimentos podem não simplesmente trazer recordações, mas, além disso, promover reflexão, desejo que modificar uma dada realidade, baseando-se nos fatos do passado. Ainda que a memória, muitas vezes, transforme-se em tradição, cabe pensar quais são as situações cultuadas, quais foram os ícones daqueles episódios e no que estes acontecimentos contribuem para a construção do que se tem hoje em termos de sociedade e posicionamento crítico enquanto indivíduos que buscam o melhor para os grupos aos quais estão inseridos. Diante desta perspectiva, podemos verificar, a partir da próxima seção deste trabalho, de que forma a abordagem da violência e da guerra podem ser representadas em diferentes discursos para, a partir de então, contribuir na formação desta memória.

\section{VIOLÊNCIA E GUERRA: REVOLUÇÃO FARROUPILHA EM O POVO E O TEMPO E O VENTO}

A violência e a guerra são elementos que já estão imbuídos na sociedade como algo do cotidiano, mas, que, logicamente, não fazem parte de uma vida almejada. A constituição da violência permeia diferentes campos da condição humana, desde físico ao psicológico, nas mais diferentes formas de tortura e opressão, os dois assuntos podem ser abordados concomitantemente.

Para Ginzburg (2013), ainda há muito a ser discutido sobre a violência que habita o mundo de hoje. Fenômenos de guerra e violência são, inexplicavelmente, inerentes à humanidade. Sendo assim, a imagem artística da violência poderia contribuir não apenas para a interpretação das obras, mas, sobretudo, para "definir critérios de relacionamento com outros seres humanos e tomadas de decisão" (GINZBURG, 2013, p. 25), colaborando para novas ponderações com relação a este tema, que não deve ser considerado como normal à sociedade.

Entretanto, a presença da violência nas obras de arte nem sempre atua 
com uma perspectiva humanizadora. Diferente disso, conforme explica Ginzburg, fatores negativos aparecem na obra, mas a solução final é positiva, ficando em evidência em detrimento da problemática. "Certos momentos de violência, longe de serem indesejáveis, são interessantes para a composição do conjunto" (GINZBURG, 2012, p. 28), enfatiza o autor, instigando a refletir se o formato como este tema aparece, é realmente satisfatório no sentido de fazer refletir ou, de outro modo, se a resolução dos conflitos quase que instantaneamente acaba por suprir os anseios do leitor que circundam mais na obtenção de valores positivos do que na construção de uma nova interpretação sobre aquilo que é negativo e como pode ser modificado.

Considerando as reflexões estabelecidas até aqui, é oportuno destacar que a representação dos fenômenos sociais através das narrativas está ligada à formação da memória social coletiva, e tanto o jornal quanto o filme contam histórias, e, portanto, expõem narrativas. Nas artes, os episódios de guerra e violência, são grandes problemas sociais que, ao serem representados, podem vir munidas por contextualizações mais amplas sobre os temas, proporcionando, em maior medida, possibilidades de envolvimento social enquanto reflexão e possíveis atitudes com vistas a modificar realidades. Considerando a forte presença da violência na história da humanidade e também a grande frequência com que a temática aparece nos mais diferentes discursos, é pertinente também verificarmos de que maneira estes elementos são abordados em narrativas não-ficcionais, como no jornalismo, que se propõe, em primeira instância, a informar correta e verdadeiramente sobre os fatos.

Seja legitimada ou não, a violência é diariamente transmitida pela mídia. Ao considerarmos os pressupostos de Muniz Sodré (1992), vemos que a violência cresce no país diretamente com o aumento populacional nos centros e com a degradação das condições de vida desta população, que perpassa por deficiência alimentar, de saúde, educação, desemprego e outros. Estes fatores, por si só, já seriam suficientes, enquanto critérios de noticiabilidade, para serem veiculados através dos canais midiáticos, sendo eles impressos, digitais ou locucionados pela televisão ou rádio.

Contudo, importa-nos não somente o motivo da divulgação, que também percorre o caminho do fazer conhecer, mas, principalmente, o modo como esta violência e as imagens da guerra são abordadas pela mídia, enquanto narrativa não-ficcional. Por isso, passamos à análise do jornal O Povo, publicado em um período em que a imprensa jornalística emitia o discurso 
era constituído com vistas a transmitir as falas oficiais do comando político, conforme explica a historiadora Marialva Barbosa (2010)'. Dessa forma o discurso de jornal ocorria no Estado do Rio Grande do Sul e Romancini e Lago (2007) afirmam que as revoluções, na primeira metade do século XIX, pautaram esse processo de construção dos textos. A imprensa, por sua vez, teve papel importante, considerando não somente a veiculação de informações na época, mas também para poder documentar os acontecimentos a fim de que hoje tenhamos acesso.

Se a imprensa escrita chega ao Brasil em 1808, é somente em 1827 que toma forma no estado gaúcho, através do jornal O Diário de Porto Alegre. Esta origem está atrelada justamente à Revolução Farroupilha, já que neste período se articulavam ideias a respeito e o presidente da Província de São Pedro do Rio Grande do Sul, Salvador José Maciel, era um dos patrocinadores do periódico lançado. Nesse contexto, deflagra-se a Revolução Farroupilha e entre jornais que findaram-se e outros que surgiram, emerge, em meio à guerra, $O$ Povo.

O jornal O Povo circulou no Rio Grande do Sul de 1838 a 1840. Foram três anos de publicações baseadas, quase que exclusivamente, nos fatos da Revolução Farroupilha, ocorrida no Estado gaúcho de 1835 a 1845. Este periódico é, entre outros, um documento muito importante na representação deste período histórico. Selecionamos este jornal em detrimento dos demais, pela representatividade histórica e ainda por estar inserido em um espaço de tempo que perfaz o que seria a metade da guerra dos farrapos.

Ao todo foram 160 exemplares de $O$ Povo, sendo 45 publicados quando a produção do jornal era em Piratini e os demais já no município de Caçapava, quando a sede do Governo se transferiu para aquele local. $O$ jornal é indiscutivelmente opinativo, e não se pretende diferente, já que em todas as edições, antes de iniciarem os textos, podemos ler, além da data, do nome e do Slogan: Jornal político, literário e ministerial da República Rio-grandense - o que já o emoldura em uma linha discursiva -, também a informação: "Este Perio-

1 De acordo com Rüdiger (1993) os periódicos desta época tinham a predominante função de difundir ideologias, sendo a circunstância política, muito mais do que os conceitos de jornalismo, que ditavam o nascimento de jornais, bem como sua continuação e fechamento. Se a política era fator de maior motivação para o surgimento e periodicidade dos jornais, as lutas políticas estimularam o crescimento da imprensa. Nelson Sodré (1999) comenta que a Revolução Farroupilha, iniciada em 1835, logo após o surgimento da imprensa, continuou a absorver as preocupações do governo e, já nesta época, os governantes passaram a comprar os jornais dos seus fundadores, a fim de veicularem as suas ideias de maneira mais direta. 
dico he propriedade do Governo". Também ao início de cada edição vemos o aviso de que as publicações serão às quartas-feiras e aos sábados e que o periódico pode ser adquirido na casa do redator ou através de assinaturas.

O discurso de O Povo é construído, principalmente, através de seções que se intitulam manifestos, com opiniões do governo ou outros articulistas convidados, comunicados, notícias, também opinativas, moral, com textos que vangloriam feitos gaúchos, além de portarias, poesias, sonetos, pensamentos, correspondências, atas, ofícios, e informes como, por exemplo, as listas atualizadas dos oficiais do exército. Em todas as publicações deste periódico há um espaço destinado à frase: "O poder que dirige a revolução, tem que preparar os animos dos Cidadaós aos Sentimentos de fraternidade, de modéstia, de igualdade e desinteressado e ardente amor da Patria. Joven Italia. Vol. V."

Considerando que se trata de um jornal do governo, este que é o poder que está à frente da Revolução Farroupilha, entendemos que a proposta do periódico é, através de seus textos, estimular a comunidade aos sentimentos citados pela frase de abertura do bissemanário. A frase de abertura do jornal é citada também logo no início do primeiro texto publicado, em $1^{\circ}$ de setembro de 1838 , sob o título de "Prospecto", sendo argumento sobre as motivações que guiarão a redação do periódico. Na sequência, o redator se propõe a explicar a expressão utilizada:

Devemos nos identificar o poder que rege a guerra, e tentar todos os meios lícitos para lhe adquirir maior probabilidade de huma decisiva victoria. Procurar com todas as nossas forças propagar entre o Povo doutrinas essencialmente democraticas, sendo aquellas das quaes depende a salvação, e a felicidade da Republica. Tal he a missão que a nossa consciencia imperiosamente nos ordena nas circunstancias. Quem se propor á outro fito além deste, teria a nosso ver, mal concebido o espírito de huma guerra de insurreiçáo. A oposição aos atos do Governo, quando o Governo he consolidado, e os regulamentos da paz substituídos aos Decretos da guerra; quando cada cousa tem que reger-se pela soberana vontade do Povo, entáo náo sómente he util, mas torna-se necessaria para advertir a Naçáo, ou das usurpaçóes do poder, ou da incapacidade dos governantes, a fim de que Ella possa promover, e obstar males, de que está ameaçada; mas quando se tenta destruir os obstaculos que embaraçáo o fim da revolução, e se considera que para vencer o inimigo he necessária huma extrema vigilancia, huma atividade incansavel, e huma celeridade extraordinaria áfim de conhecer-se seus movimentos; dar providencias as necessidades que disto se seguem, e vigiar promptamente, e em tempo sua execução. (O POVO, 1838, Ed 1, p. 1). 
Neste trecho fica claro o anseio do governo e, consequentemente, do periódico que o representa, a busca pela vitória da revolução, que poderá chegar através de muitas lutas. Ao passo em que aborda a questão da democracia como valor regente do governo, a matéria explicita a necessidade de todos estarem a favor daqueles que estão no poder. Embora pregue a democracia, o discurso deste primeiro texto do periódico também atribui valor positivo apenas aos que estão em concordância com o governo vigente, levando também ao leitor as ideias sobre como agir diante da guerra instaurada. O texto segue, mais adiante, tratando sobre o quanto seria perigoso censurar um governo que está lutando com vistas a conquistar a independência da nação.

Já a abertura do jornal $O$ povo demonstra o ideal de guerra justificável. Embora haja mortes e outras atrocidades em decorrência das batalhas, há, para os enunciadores deste discurso, um objetivo maior para que tudo aconteça. O texto apresenta, inclusive, a ideia de guerra santa, de Deus abençoando e concedendo benefícios àqueles que de fato lutam, utilizando as armas adequadamente quando em benefício de uma questão. Cabe refletirmos, de que maneira, a utilização de uma arma, com a finalidade de destruição, pode ser considerada uma maneira de elevar a santidade.

Ainda no sentido religioso, este primeiro discurso remete ao ofício do jornalista, atribuindo-lhe qualidades como "sublime" e "luminoso", sendo, o profissional desta área, responsável por ser um educador e, ainda, comparando a profissão com a vocação sacerdotal. Sob esta perspectiva, era conferida, ao enunciador do jornal, a responsabilidade de, com extrema fidelidade aos fatos, instruir a população sobre os acontecimentos, muito mais do que apenas anunciá-los. Ou seja, aquilo que era publicado no jornal tinha o intuito de atingir diretamente os leitores, na mesma medida em que o redator seria o grande responsável pelo pensamento criado ou pelo que passaria a pautar as conversas e ações.

Na segunda edição de $O$ povo, publicada na quarta-feira, 05 de setembro de 1838, o periódico apresenta como primeiro texto o título "Manifesto - do Presidente da República Rio-Grandense em Nome de seus Constituintes", artigo que seguirá em continuidade por mais duas edições - no sábado, 08, e na quarta-feira, 12. Neste primeiro, vemos a ideia de tornar o Rio Grande do Sul independente do restante do país: "Desligado o Povo Rio-Grandense da Communháo Brasileira reassume todos os direitos da primitiva liberdade; usa destes direitos imprescriptiveis, constituindo-se Republica Independente [...]" (O POVO, 1838, ed. 2, p. 1). O ideal de liberdade está presente 
neste trecho do discurso, mas, em praticamente todas as edições do jornal, endossa o objetivo do governo gaúcho e a justificativa da guerra. São utilizadas, ainda, expressões positivas para caracterizar o estado sulino, como "bom senso", "amor da ordem", "moderação que causa inveja e admiração ao Brasil”. Estes fatores podem ser atribuídos à constante preocupação em exaltar o território, reforçando a imagem rio-grandense enquanto causadora de orgulho para os habitantes deste local que devem, segundo esta perspectiva, seguir lutando pela terra.

No jornal $O$ povo também eram veiculadas algumas informações referentes às batalhas que faziam parte da guerra. Contudo, o viés destas informações sempre permeia a exaltação do estado gaúcho, seja criticando os imperiais pelos atos violentos cometidos contra os republicanos, seja pela vitória sobre os inimigos. Podemos notar esta perspectiva no texto intitulado "Pedras Brancas", publicado em 22 de setembro de 1838:

O inimigo depois da inutil tentativa de surpresa feita ao Tenente Coronel Fortunato Brandaó, querendo eff ituar a sua retirada, foi novamente acommettido nas imediações do Passo do Ribeiro pelo Capitaò José do Amaral Ferrador [...]. A escaramuça foi bastante renhida, e nos fisemos a perda de alguns homens; porem elle alem de dez feridos inclusive o famigerado Francisco Pedro de Abreu, deixou tres mortos sobreo campo, e o subalterno Theodoro José da Costa em nosso poder. (O POVO, 1838, ed. 6, p. 4).

A notícia apresenta, de maneira orgulhosa, uma das vitórias dos soldados do Rio Grande do Sul. A morte de alguns dos combatentes é encarada como algo natural - e na realidade é mesmo inerente à guerra -, entretanto, neste texto não há nenhuma referência importando-se com as vidas que se perdem, há, apenas, um “porém”, relatando que, embora alguns soldados tenham morrido, foram deixados inimigos feridos e mortos, além de um presidiário, fato que vem para justificar as mortes do lado republicano, sendo atribuída à batalha valores vantajosos a fatos de horror.

Embora em diversas edições seja evidenciado o orgulho pelos feitos considerados heroicos nas guerras, há também artigos opinativos que anseiam pela paz. Contudo, a paz é alcançada com uso de força e violência, que não são questionadas, como percebemos na edição 27 de $O$ povo, em $1^{\circ}$ de dezembro de 1838, no texto "A guerra do Rio-Grande - Meios de a terminar", que defende que "A primeira condição essencial para extinguir a revolta do Rio-Grande” é a junção de "bastante força, tanto de Terra como de Marina, naó 
só para combater os rebeldes com vantagem, mas também para estabelecer um systemade ocupação militar e Policia [...]. (O POVO, 1838, ed. 27, p. 1).

Em 06 de março de 1839, O povo começa a circular a partir de Caçapava, e abaixo do slogan que o identifica traz ainda as palavras: Liberdade, Igualdade e Humanidade. Agora o ideal de liberdade está impresso em cada uma das edições do periódico, assim como "humanidade", difícil de se conceituar em meio a um contexto em que é necessário - e possível -, matar para poder conquistar os anseios do governo. Entretanto, através do discurso adotado pelo jornal, é possível compreender que, ao menos pela representação discursiva, ansiava-se por esta humanização:

Ufanos de nossa calculada inacçaó os Imperiaes haviaó adoptado hum plano de campanha que muito convinha aos sentimentos de Humanidade que nos dirigem mesmo na terrivel necessidade da guerra. Ja effetuado nos pouparia o desgosto de sermos obrigados a acometter cidades que abrigaó todavia Rio-Grandenses que amamos. Porem se continuassemos a conservar nos taó perto de suas posiçóes, o Presidente Eliziario nunca se animaria á avançar. (O POVO, 1839, ed. 46, p. 2).

Embora o texto traga a humanização enquanto desejo e caracterize a guerra enquanto "terrível necessidade", deixa evidente que o humano volta-se apenas para aqueles que estão a favor dos ideais do governo e, como consequência, deste periódico, já que a melancolia se dá pela obrigação de invadir locais onde também existem gaúchos, entretanto, para que se cumpram os objetivos, esta é uma angústia que se faz tão necessária quanto a guerra que se estabelece.

Notamos que, ao longo das publicações, poucas são as vezes que se emitem conceitos negativos a pessoas que pertencem ao Estado do Rio Grande do Sul, e quando ocorre, é mais brevemente e, no mesmo texto, justificando que são exceções, que sua maioria preza pela terra. Esta exaltação ao povo gaúcho é tão intensa que outros articulistas, de fora do país, parecem incluírem-se neste espírito.

Já no campo das artes, não é incomum obras literárias serem referência para a produção cinematográfica. A Revolução Farroupilha é, por exemplo, abordada no filme $O$ tempo e o vento, baseado na obra literária de Erico Verissimo, de modo mais específico, em sua primeira parte da trilogia, O Continente. Nesta obra cinematográfica, fatos que aconteceram no Brasil e no Rio Grande do Sul, especialmente os episódios de guerras, contudo, trata-se 
de uma ficção, retratando estes e outros acontecimentos de viés histórico, a partir de imagens atuais, de personagens e histórias que não aconteceram veridicamente. Considerando que a ficcionalidade está presente na narrativa fílmica, o modo como se prioriza a representação de alguns acontecimentos em relação aos demais, é também fator importante no que diz respeito as formas de interpretação das informações recebidas através da película.

O filme $O$ tempo e o vento, de Jayme Monjardim, roteirizado por Letícia Wierzchowski, Marcelo Pires e Tabajara Ruas, traz, em 127 minutos, a atuação de Thiago Lacerda, como capitão Rodrigo, Cleo Pires, como Ana Terra, MarjorieEstiano e Fernanda Montenegro como Bibiana, em duas fases diferentes de sua trajetória, e Paulo Goulart como coronel Ricardo Amaral Neto, além de outros diversos atores que interpretam as personagens levando os mesmos nomes dos da obra literária. A estreia aconteceu uma semana antes no estado do Rio Grande do Sul do que nos demais estados brasileiros. A primeira exibição aconteceu no dia 20 de setembro, feriado para os gaúchos, data em que se celebra o fim da Revolução Farroupilha.

O filme apresenta como mote "A maior história de amor de todos os tempos". Deste conceito motivador para a proposta de consumo do filme, já podemos inferir o tema destaque na obra: o romance. A história de amor de Ana Terra (Cléo Pires) e o índio Pedro Missioneiro (Matheus Costa) é o que parece nortear o início desta narrativa cinematográfica, que segue com a sequência da família Terra que se funde com a Cambará, para, a partir de então, evidenciar a história de amor de Bibiana Terra (Marjorie Estiano e, posteriormente, Fernanda Montenegro) e capitão Rodrigo Cambará (Thiago Lacerda), episódios que serão mais detalhadamente analisados na próxima seção deste capítulo.

É em um cenário de guerras que se dá início ao filme, após uma imagem que representa uma paisagem tipicamente gaúcha, com o sol de pondo, um rio, e cavalos galopando. O enredo remete ao Sobrado - residência dos Cambará -, local onde transcorre a trama que envolve a Revolução Federalista. Neste ambiente, encontra-se a personagem idosa de Bibiana, matriarca da família e narradora do filme, personagem que relembra a saga de sua família e as compartilha com o espírito do capitão Rodrigo, que veio lhe visitar.

No filme $O$ tempo e o vento, podemos verificar o modo como hoje, século XXI, a narrativa sobre as revoluções Farroupilha é transposta ao discurso ficcional pelo viés fílmico. Além disso, observaremos como, neste século, a violência vivenciada há 200 anos é representada. O ele- 
mento principal desta pesquisa já foi representado não-ficcionalmente, através do discurso jornalístico.

Com essa transição temporal, em que a sociedade se modificou, os valores se alternaram - e continuam se transformando -, as guerras ainda acontecem, embora não no mesmo formato e tampouco no estado gaúcho, e a violência toma proporções avassaladoras à medida que a humanidade evolui. Além disso, narrativas ficcionais têm a possibilidade de reconstruir e transmitir o passado de forma mais reflexiva para que seja possível a relação com o atual com vistas à humanização e ao enfrentamento de situações conflitivas que necessitam ser combatidas.

A partir da narrativa ficcional que faz a releitura de episódios de guerra e violência que aconteceram no passado, seria de grande relevância a utilização de um enredo que propiciasse ponderações acerca destas temáticas. Entretanto, ao considerar a questão do consumo, ou seja, a forma como o conteúdo pode atingir a grande massa, alguns assuntos passam a ser tratados de forma não tão reflexiva quanto atrativa, aproximando-se do conceito de espetacularização. Cenas violentas, imagens de guerra, paisagens que remetem a uma identificação e histórias de amor são alguns dos fatores que, por si só, prendem a atenção do público receptor, ainda que não tenham como objetivo propiciar uma nova forma de entendimento sobre aquilo que é transmitido. Guy Debord (2003), que definiu sociedade do espetáculo enquanto a relação social entre as pessoas transposta em imagens, aborda este conceito, ainda, considerando especialmente o entretenimento, ou seja, situações são representadas muito mais com objetivo de proporcionar momentos de lazer do que propriamente de reflexão.

As cenas de violência em $O$ tempo e o vento, versão cinema, estão muito atreladas às guerras. Quando a personagem Bibiana começa a narrar como inicia a saga de sua família, os primeiros relatos dizem respeito à fuga de uma índia grávida que percorreu quilômetros até chegar aos Sete Povos das Missões, onde faleceu, mas antes disso, deu a luz ao índio Pedro, que aparece ainda criança brincando e entoando cantigas religiosas junto ao coral de crianças do povoado. Para referir-se a tal circunstância, Bibiana conta: “- Enquanto meu avô Pedro crescia sob os cuidados do padre Alonso, havia paz nos Sete Povos das Missões" (O TEMPO E O VENTO, 00:15:14 - 00:15:21 2013). Entretanto, o capitão Rodrigo que, em espírito, escuta as recordações, pronuncia sorrindo: “- Paz é uma coisa que as gentes daqui desconhecem, Bibiana” (O TEMPO E O VENTO, 00:15:22 - 00:12:26, 2013). 
À medida que Bibiana tenta recordar um período em que houve paz, o capitão retoma a informação que confirma a presença constante da violência na vida das personagens do romance. A paz, que deveria ser inerente ao ser humano, seu convívio com os demais e os valores pessoais e coletivos, deixa lugar para a violência e chega a ser tratada ironicamente, já que Rodrigo inclusive sorri para constatar esta triste realidade. $E$ as cenas que seguem no filme não são diferentes, pois, na sequência, o mesmo povoado aparece sendo atacado pelo exército de Portugal, com imagens de fogo, pessoas gritando e fugindo e uma trilha sonora de tom fúnebre, que anuncia o fim de uma população.

Os filmes, enquanto produções ficcionais, não têm a obrigatoriedade de transmitir os fatos como realmente aconteceram e tampouco de transpor para a linguagem audiovisual o que foi apresentado na literatura, quando toma esta como base. Os novos enredos são, portanto, passíveis de atualização, considerando a época em que serão exibidos, o público receptor e tantos outros fatores.

A representação da Revolução Farroupilha inicia no filme no momento em que o Coronel Ricardo Amaral convoca os homens da cidade de Santa Fé para uma reunião. A cena é apresentada com elementos típicos de guerra e regionalismo, pois os homens vão reunindo-se na praça da cidade em sua maioria montados em seus cavalos carregando bandeiras e armas. Para ouvir o que o representante do município tem a dizer, alguns se mantêm de pé e os que chegam a cavalo permanecem sobre o animal, formando um círculo ao redor do coronel que afirma: “- Todos sabem que os liberais, comandados por Bento Gonçalves querem derrubar a monarquia e separar o Rio Grande do resto do Brasil" (O TEMPO E O VENTO, 00:35:41 - 00:35:49, 2013). O líder segue seu discurso evidenciando contrariedade, não especificamente à guerra, mas aos ideais republicanos e pede que a cidade mantenha-se ao lado do governo, para evitar a desordem, esta que, de qualquer maneira, manifesta-se em tempos de guerra.

Entretanto, nem todos são a favor da ordem estabelecida, Pedro Terra, o pai de Bibiana contesta: "- Coronel Amaral, os farrapos não são desordeiros, são republicanos, pessoas com ideias eu proponho que... [...] - Vosmecê não propõe nada. A câmara representa o governo, não é uma câmara de traidores" (O TEMPO E O VENTO, 01:36:02 - 01:36:16, 2013).

Independente da opinião dos cidadãos quanto a um ou outro ideal político, o que vemos são pessoas prontas para o combate, seja ao lado dos 
republicanos, que possuem as ideias revolucionárias, ou para manifestar apoio ao governo. Reunidos apenas para uma conversa, que poderia ser um debate acerca dos temas em questão, os convidados já foram prontos para guerrear, montados em cavalos e com as armas a postos. Uma tentativa de discussão, através da opinião de Pedro Terra, levou-o a ser preso, comentário que chegou para Bibiana, que, na narrativa cinematográfica, aparece tão ou ainda mais apática do que no romance literário. "Rodrigo a esta hora já está longe. Estava louco de contente, parecia que ia pra uma festa" (O TEMPO E O VENTO, 01:36:36 - 01:36:45, 2013) . O primeiro plano focado em Bibiana não evidencia nenhuma expressão marcante, embora tenha o olhar triste, não tem reação de sorrir, chorar ou qualquer outra. A falta de atitude da personagem que representa Bibiana na narrativa cinematográfica apresenta os sentimentos de submissão e conformidade com as situações que envolvem o marido. A personagem não parece importar-se com o horror da guerra, a referência que faz é unicamente ao marido, como se a espera fosse a única ação possível, transformada em sentimento.

Entretanto, a sequência traz a voz da narradora do filme, Bibiana em idade avançada, que apresenta um pouco mais de reflexão em sua fala, embora isso aconteça com seu pensamento voltado basicamente ao seu amor por capitão Rodrigo. Neste momento, assim como em todos os outros em que a voz da narradora aparece, ela dirige-se à alma do capitão que foi visitá-la no Sobrado:

A revolução farroupilha se alastrou por toda a província. E proclamaram a república, a república rio-grandense. Eu não sabia por onde vosmecêandava, Rodrigo, mas alguma coisa me dizia que vosmecê estava bem, que vosmecê estava vivo. (O TEMPO E O VENTO, 01:37:04 - 01:37:31, 2013).

A história da Revolução Farroupilha aparece muito brevemente, não são explicitados, no filme, por exemplo, os passos para que fosse proclamada a república. Esta lembrança, para a personagem, parece ser a mais vaga, a mais rapidamente descrita, enquanto que a memória acerca dos pensamentos que levavam ao seu esposo aparecem de forma muito mais enfática.

As imagens que sucedem este momento do filme, acompanhadas pela fala de Bibiana, mostram um plano aberto com centenas de homens cavalgando por matas e riachos munidos pelas bandeiras republicanas, armas de fogo e adagas. As sombras dos cavalarianos e seus instrumentos também são mostrados ao entardecer e ao nascer do sol. Em alguns momentos desta represen- 
tação, o plano da câmera fecha em Rodrigo, que lidera o grupo, perpassando uma imagem da personagem enquanto guerreiro, exemplo diante dos demais.

Ao avisarem o coronel Amaral que os republicanos estavam chegando a Santa Fé, a expressão, exibida em primeiro plano, é de raiva. "Deixa que venham, vou receber esses anarquistas à bala” (O TEMPO E O VENTO, 01:37:38 - 01:37:43, 2013). Mesmo que o líder municipal não esteja na guerra com os demais, sua resposta é precisa e pronta para o combate.

A trilha com caráter de suspense está presente nesta parte do filme, momento em que Bibiana muito paciente conta ao irmão e a cunhada que acredita que Rodrigo voltará para vê-la e, desta forma, decide ficar na casa enviando seu filho com os familiares para encontrá-lo posteriormente. Esta cena é marcada ainda por pessoas correndo, fugindo da cidade para se protegerem, imagens estas que são alternadas com as dos guerrilheiros rumo a Santa Fé, galopando sempre precedidos por capitão Rodrigo.

A aflição de Bibiana que permanece na cidade à espera do marido, tão detalhadamente descrita no romance de Verissimo, na narrativa cinematográfica, resume-se a uma cena de Bibiana rezando com a vela acesa em frente à imagem de Nossa Senhora. Neste momento, o Capitão Rodrigo chega e, após uma tocante cena de reencontro, beijos e abraços, o esposo que está há meses fora de casa pronuncia-se: "Vou invadir o casarão, Bibiana, e vou prender os Amaral, pai e filho” (O TEMPO E O VENTO, 01:39:27 - 01:39:31, 2013). A personagem feminina mostra-se muito aflita, já não mais tão apática quanto anteriormente. Já o Capitão ri muito ao dizer: "Parece que é mentira que foi preciso uma guerra civil pra eu terminar de botar a pernita do $\mathrm{R}$ na cara do Bento" (O TEMPO E O VENTO, 01:39:33 - 01:39:38, 2013). O republicano refere-se a um duelo que teve com o inimigo antes do casamento com Bibiana, que, ao ouvir a constatação do marido, apenas sorri, sem jeito, não concordando e nem discordando da situação. Ao chegar o momento da invasão, a personagem alerta: “- Pelo amor do nosso filho Rodrigo, tenha cuidado. - A gente passa trabalho numa guerra, mas se diverte” (O TEMPO E O VENTO, 01:40:19 - 01:40:32, 2013), responde Rodrigo, sorrindo, o que comprova sua própria fala: para ele, a guerra é muito mais atrativa do que qualquer conselho ou do que a vida que levava quando estava apenas em sua casa, a personagem nem ao menos refere-se ao pedido feito por Bibiana, parece não pesar no filho, pelo menos não naquele momento, diferente do que disse quando chegou em casa, que não tirou a esposa e a criança da cabeça durante o tempo em que esteve longe. 
Enquanto Rodrigo sai com seu cavalo seguido pelos demais republicanos, Bibiana fica na porta apenas observando o rumo do esposo, que, antes de chegar ao casarão, para na igreja e chama pelo padre, que tem a fala semelhante a do livro, embora o diálogo seja reduzido, especialmente da parte do capitão: "- Toma cuidado meu filho, os Amaral são cabeçudo, têm muita munição. - Fique tranquilo, padre, ainda não fabricaram a bala que há de me matar" (O TEMPO E O VENTO, 01:41:10 - 01:41:18, 2013). Diferente do romance literário, no cinematográfico, não há nenhuma tentativa do sacerdote em deter Rodrigo para que ele repense em um diálogo antes do ataque, fala que aconteceu no texto do livro, mas não foi aceita pelo capitão. Na narrativa fílmica, este momento é muito mais de Rodrigo, sua vaidade e orgulho estão em evidência, confirmando a confiança que ele tem em si mesmo, na medida em que não demonstra, em nenhuma circunstância, medo ou receio, apenas a verdade que traz consigo, que é a de invadir o casarão e, com isso, dominar a cidade com os ideais republicanos.

Ao aproximarem-se do casarão, os aliados de capitão Rodrigo são recebidos com tiros pelos soldados do outro lado. Entretanto, reagem também com suas armas de fogo e conseguem invadir a casa, quando Rodrigo entra a cavalo na sala do inimigo e ao puxar sua espada pronuncia: "- Coronel, se me dá a honra” (O TEMPO E O VENTO, 01:42:35 - 01:42:41). Enquanto duelam sob o teto do casarão, Rodrigo sorri, como se estivesse de fato se divertindo, como havia ele mesmo comentado anteriormente.

A briga é acompanhada por uma trilha de suspense, o que auxilia a prender a atenção do espectador e parece instigar o sentimento de torcida, já que a música de fundo culminará em um acontecimento que, provavelmente, será a morte de um dos duelistas. Ao atingir o coronel Amaral com a adaga, Bento Amaral atira nas costas de Rodrigo, tiro que, no romance, não revela sua origem. $O$ fato de o capitão ter levado um tiro nas costas pelo inimigo que lutara anteriormente é um elemento que parece trilhar um caminho de indução à preferência pelo capitão republicano, tendo em vista que "atirar pelas costas" é uma expressão utilizada, inclusive neste filme em análise, não por se tratar de um ato violento, mas com a gravidade voltada à covardia. Nesta linha de interpretação, Rodrigo teria morrido de forma injusta, embora esteja, ao mesmo tempo em que é lastimado, matando seu oponente. Aliás, no longa, Rodrigo esboça mais um sorriso antes de morrer. Esta cena do longa demonstra o modo como Rodrigo pode, inclusive, ter sentido alegria ao perceber que sua morte deu-se em meio a uma batalha, 
assim como mencionou ser a saga dos demais homens da família. A encenação da morte do capitão acontece quase que de forma positiva, já que seu sorriso, desta vez, ironiza sua própria morte.

\section{CONSIDERAÇÕES FINAIS}

Ao analisarmos o modo que a violência, especialmente através da Revolução Farroupilha, foi abordada em dois discursos, o jornalístico e o cinematográfico, podemos perceber algumas questões importantes acerca do modo como a memória se constitui a partir destes textos. Se os jornais surgiam para difundir ideologias, acontecimentos políticos e informações de guerra, o povocumpriu este papel, utilizando-se muito mais da política do que dos conceitos jornalísticos para veicular as informações, conforme nos apresenta Rüdiger (1993). De leitura não muito facilitada, pelas falhas na impressão e pelo modo como as palavras eram escritas naquele período, o jornal assumia características literárias em sua linguagem, bem como explicou Sodré (1999), mas, mais do que isso, foi pautado, quase que exclusivamente pelos acontecimentos da Revolução Farroupilha, confirmando sua importância no entendimento circunstancial daquele período.

Todavia, precisamos separar o que era informação e o que se tratava de ideologias. A questão da violência aparece em $O$ povo somente atrelada às guerras, não sendo noticiados outros episódios violentos que por ventura ocorressem fora do contexto de batalhas. Já a Revolução, por muitas vezes foi descrita de modo que podemos compreender os horrores promovidos a partir dos combates, sem que necessariamente o discurso aponte para os fatos enquanto sendo barbáries. Ademais, há uma via única na transmissão destes fatos: o Estado rio-grandense como superior, os gaúchos como figuras que se orgulham do seu estado e homens valentes, heróis, que defendem esta terra acima de tudo.

A memória constituída através de $O$ Povo não difunde uma visão crítica sobre a guerra, pois, apesar de divulgar fatos trágicos decorrentes das batalhas, os textos não os apresentam como consequências negativas de uma revolução, constituindo uma memória que envolve apenas uma versão dos acontecimentos. Já o filme $O$ tempo e o vento expõe a revolução de uma forma glamourizada, tendo em vista que os ideais pelos quais lutam e os líderes que tomam à frente da guerra, estão acima da dor que elas causam ou mesmo das mortes decorrentes das batalhas. A guerra é exposta através 
de episódios fatídicos que são justificáveis quando se pensa na vitória, do fato de um grupo sobressair-se diante dos demais. A busca pelos interesses através de atos violentos aparece como se estivesse institucionalizada desta maneira, e os meios e resultados das guerras são vistos pelas personagens muito mais como fatores positivos do que como situações de tragédias e perdas. A Revolução não é apresentada em detalhes históricos, com as motivações para terem ocorrido ou de que forma terminavam. As cenas de batalhas, apresentadas junto com trilhas marcantes, com certo suspense que prende a atenção do espectador, parecem demonstrar muito mais a bravura dos soldados que lutavam por seus objetivos do que os horrores vivenciados em tais duelos. O que está mais evidente no longa é sempre a história de amor das personagens. Deste modo, a memória construída a partir do discurso do filme $O$ tempo o ventonão propiciaria novas formas de compreender as revoluções gaúchas, mas suscitaria, em maior medida, o apreço pelo aspecto romanesco explícito no filme.

Considerando a constituição da memória como um processo coletivo, oriundo de diferentes experiências, nem sempre unicamente pessoais, como já pesquisamos em Halbwachs (2006), temos a revolução enquanto parte da história real da humanidade e a representação fílmica, que enfatiza mais o discurso em uma história de amor. Sendo assim, enquanto a narrativa cinematográfica enfatiza o amor entre as personagens e a superação de barreiras como parte do contexto de guerra, a memória formada a partir dessas informações pode correlacionar as situações amor e guerra atribuindo, em última instância, valor positivo a estes fatos.

Outra memória suscitada a partir das cenas é a valorização do herói constituído, que não é questionado por suas atitudes negativas, mas exaltado por estar a frente de um grupo de batalhas defendendo a terra ou seu próprio nome. Ao citar Araújo e Fischer, Ginzburg (2012, p. 272) trata a respeito da "ética heroica" que se forma sob uma "perspectiva positiva da guerra, como instrumento de busca de valores positivos - bem, amor, bondade, justiça". O discurso nesta perspectiva valoriza a guerra, atribuindo o heroísmo àqueles que estão a frente destas condições, esta ética heroica, de acordo com o estudioso, eleva a guerra a uma afirmação social. Se estas questões aparecem de forma glamourizada e, por vezes, espetacularizada, a memória histórico-social constituída a partir do enredo apresentado é elaborada de modo a acentuar a guerra e seus heróis como elementos com valor positivo. 


\section{REFERÊNCIAS}

A GUERRA do Rio-Grande - Meios de a terminar. O Povo. Piratini, p. 1 - 2, $1^{\circ}$ dezembro 1838.

BARBOSA, Marialva. História cultural da imprensa: Brasil, 1800 - 1900. Rio de Janeiro: Mauad, 2010.

BENJAMIN, Walter. Sobre o conceito de história. In: . Magia e técnica, arte e polí-

tica: ensaios sobre literatura e história da cultura. Trad. Sérgio Paulo Rouanet. São Paulo: Brasiliense, 1994. p. 222-232.

DEBORD, Guy. A sociedade do espetáculo. Trad. www.terravista.pt/IlhadoMel/1540. 2003. Disponível em: < http://www.cisc.org.br/portal/biblioteca/socespetaculo.pdf>. Acesso em: 10 jul. 2014.

GINZBURG, Jaime. Literatura, violência e melancolia. Campinas, SP: Autores Associados, 2013.

Paulo/Fapesp, 2012.

. Crítica em Tempos de Violência. São Paulo: Editora da Universidade de São

HALBWACHS, Maurice. A memória coletiva. Trad. Beatriz Sidou. São Paulo: Centauro, 2006.

MANIFESTO - do Presidente da República Rio-Grandense em Nome de seus Constituintes. O Povo. Piratini, p. 1 - 2, 05 setembro 1838.

MONJARDIM, Jayme. O tempo e o vento. Edição colecionador. Paris Filmes, 2013.

PEDRAS Brancas. O Povo. Piratini, p. 4, 22 setembro 1838.

PESAVENTO, Sandra Jatahy. A Revolução Farroupilha.São Paulo: Brasiliense, 2003.

PROSPECTO. O Povo. Piratini, p. 1, $1^{\circ}$ setembro 1838.

ROMANCINI, Richard. LAGO, Cláudia. História do Jornalismo no Brasil. Florianópolis: Insular, 2007.

RÜDIGER, Francisco. Tendências do jornalismo. Porto Alegre: Universidade UFRGS, 1993. SODRÉ, Nelson Werneck. História da imprensa no Brasil. 4 ed. (atualizada). Rio de Janeiro: Mauad, 2009.

SODRÉ, Muniz. O social irradiado: violência urbana, neogrotesco e mídia. São Paulo, Cortez, 1992. 


\section{Laísa Veroneze Bisol}

Jornalista, Mestra em Letras, pela Universidade Regional Integrada do Alto Uruguai e das Missões - URI câmpus Frederico Westphalen. E-mail: bisol@uri.edu.br.

\section{Luana Teixeira Porto}

Doutora professora no Programa de Pós-Graduação em Letras - Mestrado em Letras na Universidade Regional Integrada do Alto Uruguai e das Missões - URI câmpus Frederico Westphalen. E-mail: luana@uri.edu.br. 
